\title{
An Empirical Study of Peer Assessment in Public Speaking Class
}

\author{
Huiyu Ma ${ }^{1, a}$ and Yun Shen ${ }^{2, b}$ \\ ${ }^{1} 765$ Weyburn Ter Apt 315, Los Angeles, California, United States \\ ${ }^{2}$ No. 1, Nanli Community, Dingfuzhuang, Chaoyang District, Beijing, China \\ a huiyuma729@ucla.edu, b shenyunsyun@163.com
}

Keywords: Peer assessment; Public speaking course; English Teaching

\begin{abstract}
As a new way of assessment, peer assessment has been increasingly applied in Second Language Teaching in modern times. This paper aims to adopt peer assessment in public speaking class and explore whether it has an influence on students' public speaking ability. Through analyzing their performance of pre-test and post-test concerning public speaking assignments, recordings and written feedback, the author finds that students' depth comments increase while surface comments decrease, besides, they can apply what they learn from other performances to their own speaking exercises. This indicates that peer assessment helps to improve students' public speaking ability.
\end{abstract}

\section{Introduction}

Teaching assessment is an indispensable element in pedagogical teaching and learning, influencing the arrangement of teaching contents, the selection of teaching methods, and the result of teaching. (Fan, 2014) Traditionally, teachers determines what should be assessed and what criteria and standards should be used. However, people now realize the importance of other assessment including peer, self and collaborative assessment methods. Dochy (2001) particularly emphasized that the idea of using assessment as a learning tool. It is a critical shift from student-oriented paradigm to learner-oriented in that during the process, both students and teachers can learn from and improve the present situation. Students can be more independent and teachers have more suggestions to refer to and thus make better decisions.

Peer assessment is also called peer review, peer feedback, peer critiquing, peer response, peer evaluation and peer editing. The author uses peer assessment in this paper. The underlying theory of peer assessment is mainly Vygotsky's (1978) notion of scaffolded learning as one of the theoretical foundations of peer assessment. This concepts is rooted in sociocultural theory which is based on the work of Vygotsky and his colleagues. According to Lantolf (2000), Vygotsky conceived of the human mind as a mediated mental activity. Vygotsky (1978) defined the zone of proximal development (ZPD) as "the distance between the actual developmental level as determined by independent problem solving and the level of potential development as determined through problem solving under adult guidance or in collaboration with more capable peers".

English public speaking course mentioned in this paper is a professional compulsory course setting up for non-English major students in Beijing International Studies University (BISU). This course is set up to meet the goal of inter-disciplinary and high-level talent. The application of peer assessment in public speaking class is also of great necessity. Ye (2014) finds that peer assessment in public speaking class has several benefits.

Generally speaking, since public speaking class is a rather new subject, only a few studies have been done in this class. Therefore, this paper aims to make contribution to this field.

\section{Research Design}

The research questions can be listed as follows:

1) What's the effect of peer assessment on students' ability in using speech techniques? 
2) What's effect of peer assessment on students' ability in target language?

3) If there is a positive effect, in what aspect can students enjoy the biggest benefits concerning using target language and speech techniques?

\subsection{Participants}

Participants in this experiment are 32 sophomore students from Beijing International Studies University who major in tourism management and are in the same public speaking class. They have taken public speaking class for two terms and have some background knowledge about this course. Many of them are able to recite short articles fluently and correctly, appropriately use learned vocabulary and sentence patterns in classes or daily conversations and understand and fill out common forms. Some of them have higher level of English, and they are able to 1) integrate listening, speaking, reading and writing skills and properly use in all communicative situations, 2) understand daily conversations, brief stories or broadcast and describe major points, 3) comprehend short essays and summarize main ideas, 4) repeat primary points orally or in written forms.

\subsection{Instruments}

In the first of this class, the teacher has offered students training on English speeches. The teacher told them the assignment at the very beginning of the class. Each week two students are required to do a mini-speech, which last 3 to 5 minutes and whose topic is free to choose. In the second week, students had an opportunity to discuss and negotiate assessment criteria for the oral presentations and designed Peer Evaluation Rating Scale with the teacher. The rating scale for the mini-speech part is shown in table 1 . After each mini-speech, two students will be asked to make comments on the presentation, after which the teacher will conclude and comment on students' performance. Thus, each has a chance to do a mini-speech and about two times to evaluate others' performance. In order to ensure fair chances, the teacher will ask some students who are not so active for advice.

\begin{tabular}{|c|c|c|}
\hline $\begin{array}{l}\text { Content } \\
\text { (15) }\end{array}$ & $\begin{array}{l}\text { 10 15:Approriate title; } \\
\text { introductory paragraph, topic is } \\
\text { stated, leads to body; }\end{array}$ & $\begin{array}{l}0 \sim 10: \text { Inappropriate title; ineffective } \\
\text { introductory paragraph; unrelated to the } \\
\text { topic chosen }\end{array}$ \\
\hline $\begin{array}{l}\text { Expression } \\
\text { (20) }\end{array}$ & $\begin{array}{l}\text { 15 20: Good use of language; good } \\
\text { pronunciation; few grammar } \\
\text { mistakes; good intonation; good } \\
\text { cohesion and good logic. }\end{array}$ & $\begin{array}{l}0 \sim 15: \text { Poor in language use; poor } \\
\text { pronunciation; quite a lot of grammar } \\
\text { mistakes; poor intonation ; poor } \\
\text { cohesion and logic }\end{array}$ \\
\hline $\begin{array}{l}\text { Fluency } \\
\text { (15) }\end{array}$ & $\begin{array}{l}\text { 10 15: Very fluent in delivering } \\
\text { speeches; no unnecessary repetitions; }\end{array}$ & $\begin{array}{l}\text { Not so fluent in delivering speeches; } \\
\text { lots of unnecessary repetitions; }\end{array}$ \\
\hline $\begin{array}{l}\text { Techniques } \\
\text { (40) }\end{array}$ & $\begin{array}{l}30 \sim 40 \text { : Proficient in using techniques } \\
\text { in all the three parts (introduction, } \\
\text { body and conclusion) }\end{array}$ & $0 \sim 30$ : Using less than three techniques; \\
\hline $\begin{array}{l}\text { Time } \quad(3 \sim 5 \\
\min )(10)\end{array}$ & $\begin{array}{l}\text { 10: Time is well controlled within } 5 \\
\text { minutes and no less than } 3 \text { minutes. }\end{array}$ & $\begin{array}{l}\text { Less than } 3 \text { minutes or more than } 5 \\
\text { minutes }\end{array}$ \\
\hline
\end{tabular}

\subsection{Procedures}

Table 1 Holistic Rating Scale for Mini-speech

The cycle scheme used here is adopted from Peng's pattern (2009) in which he divided the cycle into three phases, i.e. pre-implementation, implementation and post-implementation phase. Detailed procedures are shown in Table 2.

Qualitative and quantitative methods are combined in this study to analyze students' comments on others' speeches and their own improvement in speaking presentation. It should be noted that recorder is used to keep track on students' oral expression including comments and their own speeches. Usually as for peer assessment in a writing class, types of assessment can be grouped into two parts: surface feedback and depth feedback. Surface feedback mainly refers to language forms problems such as spelling, tense and grammar mistakes. While depth feedback usually concerns the main idea, the content and structure. It is known that public speaking integrates writing with speaking, thus 


\begin{tabular}{|c|c|}
\hline Phase & Procedure \\
\hline Pre-implementation & $\begin{array}{l}\text { 1. Student training: Explaining the benefits, concepts, and } \\
\text { purposes of Peer Assessment and giving them chances to } \\
\text { design their own rating scale for mini-speech. } \\
\text { 2. Assessment criteria and percentage: Discussing and } \\
\text { negotiating assessment criteria and percentage with } \\
\text { students. }\end{array}$ \\
\hline Implementation & $\begin{array}{l}\text { 3. Implementation: } \\
\text { - Demonstrating how to conduct Peer Assessment to give } \\
\text { guidance on detailed procedures and to increase their } \\
\text { confidence as well as to lower their anxiety } \\
\text { - Monitoring the Peer Assessment } \\
\text { 4. Evaluation } \\
\text { The students' performances are judged by both students and } \\
\text { the teacher. }\end{array}$ \\
\hline Post-implementation & $\begin{array}{l}\text { 5. Outcomes and Investigations: } \\
\text { - Analyzing the shift of students' comments } \\
\text { - Comparing students' performance of two mini-speeches } \\
\text { and figuring } \\
\text { 6. Questionnaire: } \\
\text { 7. Improvements and modifications to schemes: Identifying } \\
\text { problems and striving for better results for future } \\
\text { implementation }\end{array}$ \\
\hline
\end{tabular}

Table 2. Phases and Procedures for Implementing the Peer Assessment

involving more elements. Thus the author still divides students' comments into two groups. On the one hand, comments on language forms are concluded as surface feedback, which involves pronunciation, fluency, speed, non-verbal gesture and errors of visual-aid. On the other hand, comments on contents, structure as well as speech techniques are concluded as depth feedback. During the process, the teacher keeps record of students' performance.

In order to solve the second research question whether peer assessment exerts an influence on their performance of using target language. The focus of measuring this facet is the quantity of comment on others' performance and their language quality, including fluency, pronunciation, intonation, word variety and sentence structure.

\section{Findings and Discussion}

\subsection{The Impact of Peer Assessment on Using Speech Techniques}

After analyzing the recordings, the author finds that students' comments tend to shift from surface ones to depth ones, which is shown in table 3. This indicates that peer assessment did influence the types of students' comments. As time goes by, students are able to make more profound comments and during this process, their surface comments drifted away.

\begin{tabular}{|l|l|l|l|l|l|l|l|l|l|l|}
\hline Week & 1 & 2 & 3 & 4 & 5 & 6 & 7 & 8 & 9 & 10 \\
\hline $\begin{array}{l}\text { Surface } \\
\text { comments }\end{array}$ & 35 & 32 & 29 & 25 & 20 & 21 & 15 & 13 & 10 & 10 \\
\hline $\begin{array}{l}\text { Depth } \\
\text { comments }\end{array}$ & 0 & 2 & 5 & 13 & 14 & 17 & 19 & 23 & 25 & 27 \\
\hline 总和 & 35 & 34 & 34 & 38 & 34 & 38 & 34 & 36 & 35 & 37 \\
\hline
\end{tabular}

Table 3 Counts of Different Types of Comments 


\section{Graph 1 The focus of peer assessment}

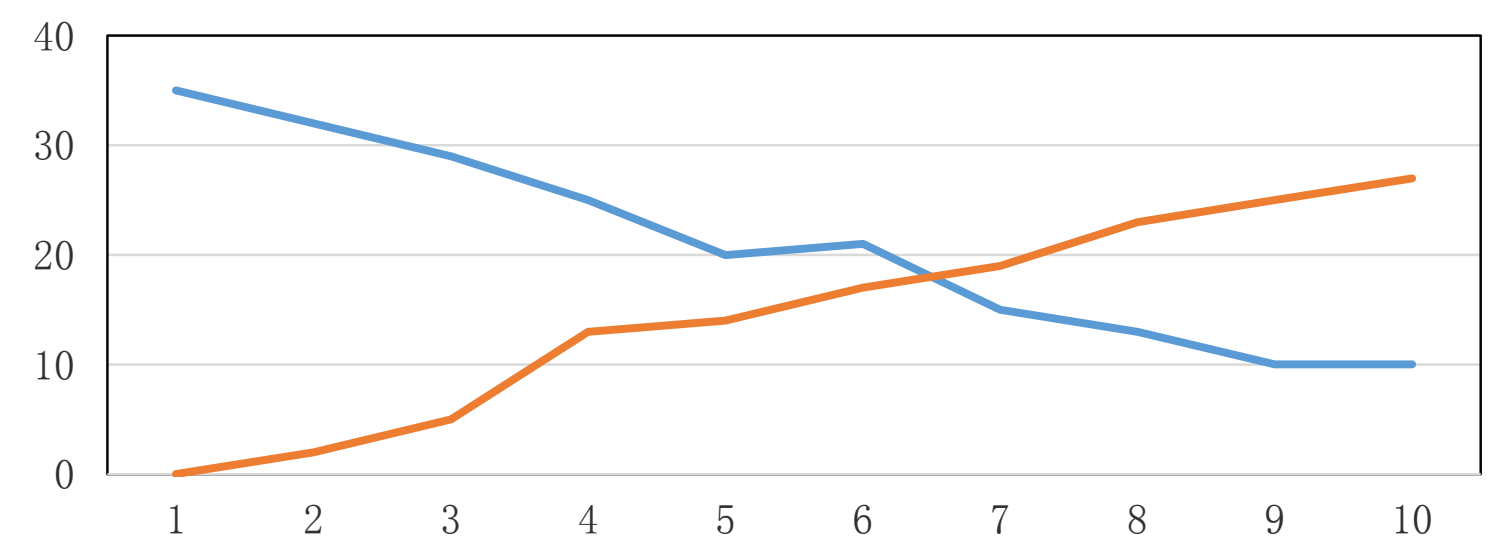

From graph 1, it is not hard to find that there are three stages. During the first stage, the comments centered on surface parts, grammatical mistakes, language fluency and language pronunciation, improper use of PowerPoint, etc. And then, four weeks passed, there are more and more depth comments and surface comments are gradually decreasing. It means that students get used to the peer assessment model and they know how to give more profound insights. They begin to care about technique use, the structure of the speech, the main theme and supporting materials. In addition, students realize there may be some problems in development part, overlapping viewpoint, and some speeches are absence of supporting materials. These problems need students' deep thinking, long-term observation and cognitive efforts. Thus, it seems that peer assessment helps student to internalize difficult points not only in language part but also in technique using part. This kind of practice gives lots of opportunities to apply what they have learnt into reality so as to improve their speech ability.

\subsection{The Comparison of Two Speeches' Score}

Participants of this study have to do two speeches. The teacher will mark on these two parts. The rating scale of two speeches is what the students have designed in the beginning of this semester. It is a holistic rating scale. Altogether there are five parts: content (15\%), expression (20\%), fluency (15\%), Techniques (40\%) and also time control (10)

Comparing the speeches of two times, the author concludes the following findings.

$\Rightarrow$ T-Test

\begin{tabular}{|c|c|c|c|c|c|}
\hline \multicolumn{6}{|c|}{ Paired Samples Statistics } \\
\hline & & Mean & $\mathrm{N}$ & Std. Deviation & $\begin{array}{l}\text { Std. Error } \\
\text { Mean }\end{array}$ \\
\hline \multirow[t]{2}{*}{ Pair1 } & 前测 & 82.06 & 32 & 9.648 & 1.706 \\
\hline & 后粀 & 85.16 & 32 & 7.327 & 1.295 \\
\hline
\end{tabular}

\begin{tabular}{|c|c|c|c|c|}
\hline \multicolumn{5}{|c|}{ d Samples Correlations } \\
\hline & & $\bar{N}$ & Correlation & Sig. \\
\hline Pair & 前制 \& 后刨 & 32 & .832 & .000 \\
\hline
\end{tabular}

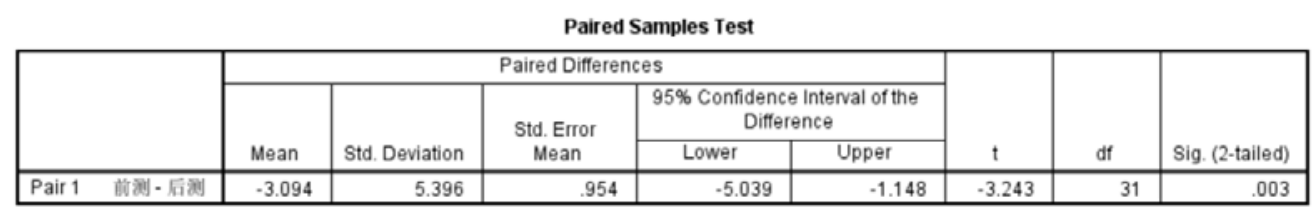

Through paired-samples t test, there is a significance difference between students' scores of two speeches $(\mathrm{t}=-3.243, \mathrm{df}=31, p<0.05)$. The scores of the first speech is obviously lower than those of 
the second speech $(\mathrm{MD}=-3.094)$. It proves that peer assessment did exert a positive effect on students' speech ability.

After analyzing students' recordings of the second speeches, the author found that students benefit most in technique using. For example, students in public speaking class are asked to do speech by using speech techniques, but it is a critical problem for them to understand how these techniques can be utilized. Peer assessment is a good way to help them understand such techniques since the author found one of the students used this skill in the first speech. She prepared a speech whose topic was tiger mother. At the beginning, the student presented the audience two questions: "Do you parents want to kill you? Do your parents kill you dreams?" It is apparent that she managed to use such a technique. Later, a student comments that it is a good technique so later she used this technique in her final examination. She began her speech by saying "I have to confess a thing that I am a lesbian”. It is no doubt that she just used this technique, which has a very impressive effect to startle all the audience.

\section{Conclusions and Future Implications}

This study investigated possible language proficiency differences and technique use in peer assessment in an EFL context. Differences about students' types of comments have been counted to reflect the effect of peer assessment on technique using. Effect on their holistic performance was examined within the context of oral presentation which is in the form of two mini-speeches. After empirical exploration, results suggested that students tend to make more depth comments and less surface comments. It indicates that they are able to have a deep thinking about more complicated contents, like logic, technique use, transition, unity and so on instead of language forms errors and use of visual-aids. Besides, by using Paired-sample t test to examine pre-test and post-test, the author finds there is a significant difference between them. Besides, according to their written feedback, they consider peer assessment a good way in public speaking class and claim that they benefit most in the use of speech technique.

Admittedly, there exist some shortcomings in this study. First of all, more comprehensive questionnaire should be designed. Besides, all the marks on two speeches are made by the author along, thus the reliability of the test needs to be improved in the future. Last but not the least, there could be more analysis on students' language improvement.

\section{References}

[1] Dochy, F. A new assessment era: Different needs, new challenges[J]. Research Dialogue in Learning and Instruction, 2001, 2, 11-20.

[2] Lantolf, J. P. Introducing sociocultural theory. In J. P. Lantolf (Eds.), Sociocultural theory and second language learning (pp. 1-26). New York: Oxford University Press. 2000.

[3] Peng J F. Peer Assessment of Oral Presentation in an EFL Context.[J]. Proquest Llc, 2009, 6(4):1-14.

[4] Vygotsky L S. Mind in Society: The Development of Higher Psychological Functions[J]. Russian Social Science Review, 1977, 18(3).

[5] Fan Jie. The application of formative assessment in the teaching of English major speech [D]. Shanxi University of Finance and Economics, 2014.

[6] Ye Ping. Research on the application of peer review in English speaking class [J]. Foreign Language Teaching, 2014, 35(4):46-50. 